\title{
超高真空技術とその物性研究への応用 (2)
}

\section{3. 超高真空と金属}

\section{（1）清浄な金属表面}

タングステン，モリブデンなどの高融点金属を真空中 で $2000^{\circ} \mathrm{K}$ 以上に加熱すれば，表面の酸化物扣よび污染 が熱分解するかまたは蒸発し，乙か子金属は蒸発しない ため，その直後からこの表面がらたたび気相からガスを 吸着する⿱での間は清浄な表面を保ちうる。この保持時 間は気体運動論によると, もし残留ガスが酸素で表面に 衝突した分子が全部解離吸着するものとすれば，10-6 $\mathrm{mmHg}$ という普通の高真空では $300^{\circ} \mathrm{K}$ で約 1 秒のうち に単原子層によつて被覆されてしもらが，10-10 $\mathrm{mmHg}$ の超高真空では約 7 時間かかるので，渡浄な表面につい て実験するのに充分な時閂がある。このように超高真㘹 技術の発展によつてはじめて清浄な表面をつくり，また 調べることが出来るよ5になつたので, それ以前の表面 現象の研究報告はすべて再検討せねばならなくなつた。 たとえば，金属の外部光電效果は表面の性質に強く依存 するが，以前は完全に清浄な表面が短時間で得られなか つたために，信頼出来る测定值を得るためには 100 時間 以上の排気とガス出しをする必要があるというような事 情が知られていただけで，真空度に関する深い反省はな されていなからた。

上記の flash-filament 法によらないでも, 超高真空 中で充分に注意して金属を蒸着すれば清浄な金属表面を 得ることができる.フラッシェ法が使えない金属にも適 用でき表面積を大きくとれる利点があるが，繰り返しが きかないことと清浄さを確保するための実験技術が面倒 な欠点がある，ともかくこのような方法によらないと， 污染の吸着熱は $100 \mathrm{kcal} / \mathrm{mole}$ 程度に達するものもある ので, 清浄な表面を作るのは難しい. 以下に最近の超高 具等技術によつて新しく開拓された金属表面現象を紹介 する.

\section{(2) Sticking probability $と$ Flash desorption}

フラッシュ法によつて清浄な表面を作り，これにガス を接触させると，吸着に応じてガス圧力が減少するの で, 気体運動論的な表面への衝突分子数亡, 実際の圧力変 化との関係から，衝突分子が 1 回の衝突で表面に捕捉さ れる確率 (sticking probability) を求めうる(22)。この付

* 電々公社電父連信研究所小林特別研究空

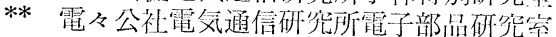

(22) J.A.Becker: Adv.in Catalysis, 7 (1955) , 136 その他
織田善次郎* 水島宣 彦**

着確率は表面が清浄でおると非常に大きく，通常室温以 下では 1 に近い数字で, 温度が高くなると小さくなるこ とがわかつた，その例を第 9 図に示す。はじめは衝突が

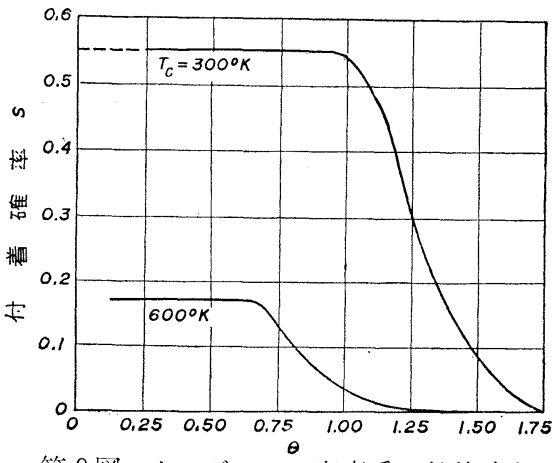

第 9 図 タングステン窒素系の付着確率 (Becker)

スは汪とんど捕えられるが，吸着原子間相互作用のため 吸着熱が次第に低下し，付着確率は急激棌小さくなり吸 着層の発達は非常に扣そくなる，表面が污れていると付 着確率ははじめから小さく，面が清浄であると大部分の 吸着は初期の早い吸着部分で占められることがわかつ た、第 9 図から表面の吸着のエネルギ状態図などが推定 できる、このような研究は蒸着膜でも試みられて扣り, また半導体でも調べられた，半導体では金属より一般に 小さい. その例を集めたものを第 1 表に示す。

第 1 表 付 着 確 率 (室 温)

\begin{tabular}{c|c}
\hline $\begin{array}{l}\text { タングステン: 窒素 } \\
\text { 多結晶面 }\end{array}$ & $0.55 \sim 0.1$ \\
シリコン: 酸素 & \\
$(100)$ 面 & $0.04 \sim 0.01$ \\
$(111)$ 面 & $0.18 \sim 0.10$ \\
ゲルマ=ウム: 酸素 & \\
$(100)$ 面 & $10^{-1} \sim 10-2$ \\
$(111)$ 面 & $10^{-4} \sim 10^{-3}$ \\
\hline
\end{tabular}

一旦フラッシュして清浄にしたフィラメントに特定の ガスを吸着させて报き，これを超高真空中で加熱する と, 吸着ガスのうち弱く結合していた部分は低温で, 強 い部分は高温で脱着するため, 生力変化を観察すると第 10 図のような曲線が得られる(23)。これを解析してもと の吸着エネルギ状態を定量的に知ることができる，図示

(23) T.W.Hickmott and G.Ehrlich : J.Phys.Chem. Solids, 5(1958) ,47 ; G.Ehrlich : J.App1.Phys., 32 (1961)，4 その他 
したタングステン一空素系では $200^{\circ} \mathrm{K}$ 以下で脱着する状

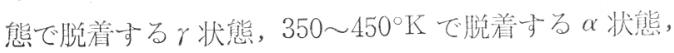

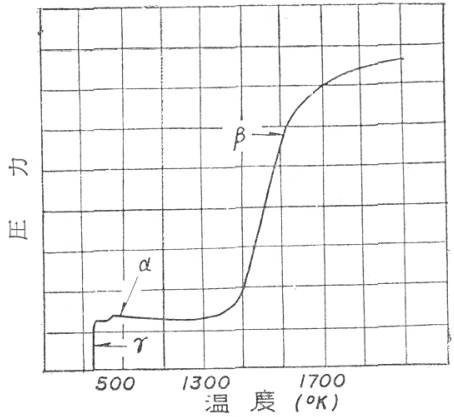
flash-desorption 曲線 (Ehrlich)
第 10 図 タングステン窒素系の

$1350 \sim 1800^{\circ} \mathrm{K}$ て 脱着する $\beta$ 状態の 三つが存在するこ とがわからた、酸 素, 水素, $\mathrm{CO}$ どもやはり二つの 状態があることが わかり，吸着状態 についているいる の取扱いがなされ ている。

このようにして 表面比着した吸着原子は下地の金属の結晶方位と適当 な幾何学的位置をとつて灾定する。この閏題は低速電子

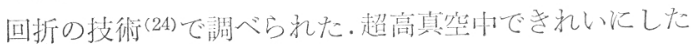
チタンの (0001) 面に銅等原子層程度蒸着与ると, 銅の

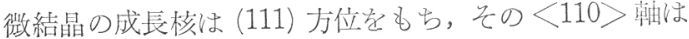
下地の〈110〉軸によつてさめられる。も乙単原子層程 度の酸素がすで吸着していると，方向性は失われてし まう。ニッケルの (100) 面上の吸着水素は下地の 2 倍の 格子間隔圭もち, チタンの (0001) 面上の窒素および酸 素は下地と同じ構造和上び格子間隔をとることがわから た。ニッケルの (100) 面上飞酸素原子が吸着する際, 下 地の〈110〉方向に並九でから不規則になっ，これが整 列しはじめるとなっ゙ニッケルの 2 倍周期の 2 次元正方格 子ができ，ついで同周期の単純正方格子となり,ついで (110) 万位の $\mathrm{NiO}$ 格子がでさた。これら吸着層はイオン 衝撃による表面に格子欠陷が出るとき著しく，㶿鈍し て欠陷をら方減少した。

第 11 図にはニッケルの (111) 面狈吸着した窒素原子の 2 次元構造と，下地のニッケル原子との相対的関係には

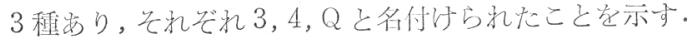
その他の組合せ孔いるいる破究されている。

(3) 金属と吸着ガスの電子的相互作用

金属のガス吸着の实筷は多い汗れぞも，真に清浔であ ることが保証された表面については少い。ここでは超高 真空の效果をよく示す吸着電気抵抗効果(20)(25)について 述ベる.1953年にニッケル蒸着膜の電気抵抗が水素吸

(24) T.H.George, H.E.Farnsworth and R.E.Schlier : J.Chem.Phys., 31 (1959), 89 ; L.H.Germer: E. J. Scheibner and C.D.H. Hartman: Phil. Mag., 5(1960), 222 ; L.H.Gemer : J.Appl.Phys., $31(1960), 2085$.

(25) Z.Oda and H.Arata: J.Phys.Chem.,62(1958), 1471 .
着によつて減少することが発見され，当時はこの原因と して水素原子が解崔しプロトンと電子とになり，この電
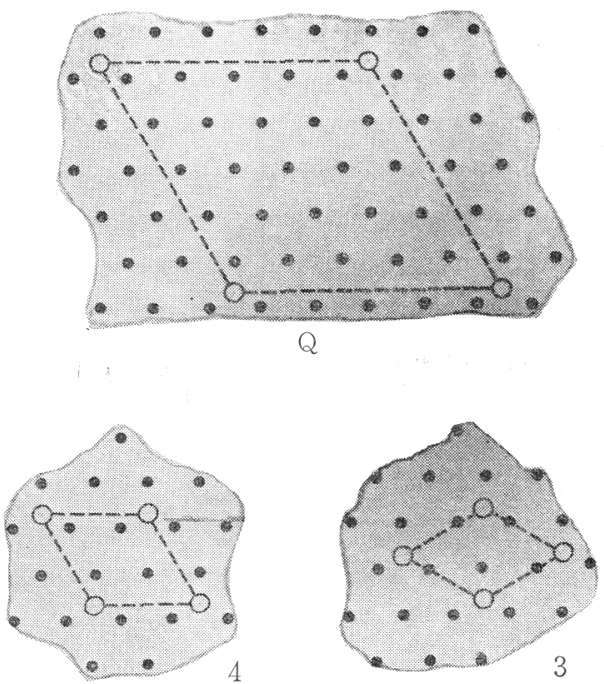

第 11 図ニッケル上の窒素 2 次元格子 (Germer)

子が自由電子として電気伝導参加するものと解瀵せら れた、酸素四着のときルは膜の抵抗がふえるので酸䒺が 真イオンとなつたと考光ればよい，その後真空技術の進 歩により 10-8 $\mathrm{mmHg}$ 程度の真空に沶いて水素吸着によ る電気抵抗は逆に増加するらしいことがわかり, 結局 10-10 $\mathrm{mmHg}$ 程度の超高真空に特いて充分清浄な表面

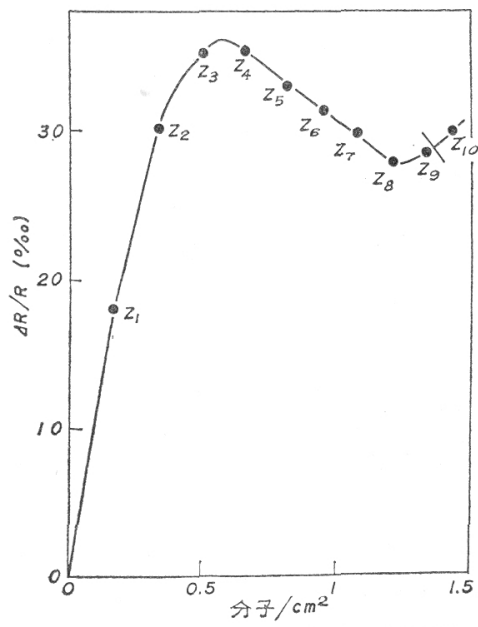

第 12 図二ッケルー水素系の抵抗変 化 $\left(-183^{\circ} \mathrm{C}\right)$ (Mizushima) が得られるに 至つて真实が わからた。可 なわ方第 12 図示示よ 5 飞, 抵抗增加 孝括こ与初期 解離吸着之, 抵抗減少老括 こす後期解離 吸着とが朝 り，図示した 低温ではさら に抵抗増加を 扣こす分子吸 着も存在する。真空がわるくて表面が清浄でないと，表 面酸化物のため初期の抵抗增加部分が観測されず, 主と 乙て次の抵抗減少が観测されることになる。実駼の定性 的再现性学確保するためだけでも 10-8 $\mathrm{mmHg}$ の真筀が 必要で，定量的結果には10-10 $\mathrm{mmHg}$ ガ必要である。こ 
のように超高真空技術によつて, 従来の真空技術による ものとは相反する観測結果さ兄生むことがあり，また吸 着状熊が単一でなくいろいろの状態があるといらことも 最近わからてきたことである。

\section{(4) 清浄表面のAuger ejection(26)}

清净度金属の表面に運動エネルギをもつイオンが接近 するときには, 固体内部の電子が Auger 効果的に励起 され，それが外部に放出される。これはイオン衝撃によ る2 次電子放射現象であるが，この放射比怟低ェネルギ 現象のため表面の状態渄常に依存するので, これによ つて表面現象を調べることもできる，超高真空でフラッ シュした清浄な表面では放出電子が出やすいので放射比 が大さく，そのエネルギ分布の巾も広いが，面が污れる 之速い電子を失つて分布の市が狭くなり放射比 $\gamma_{i}$ が低 下する.モリブデンに $200 \mathrm{eV}$ のーリウムイオン衝撃の 場合, 単分子層の窒素吸着によつて $\gamma_{i}$ は 0.22 から 0.18 になるこの原因としては仕事函数の变化ばかりでな く, 非 Auger 効果的な相互作用も考光られている。 こ のようなイオンと清浄な金属表面の相互作用はタングス テン対ネオン, アルゴン, クリプトン, クセノンなどの イオンについて調べられ，低速度イオンと固体との相互 作用以つき種々の興味ある結果が得られている。イオン でなくとも準安定励起原子も電子放射を招こすので, 励 起原子の検出にも利用できる. この方法は最近半導体に 応用されて結晶面隹よ差やエネルギ分布などから半導 体のエネルギ状態が論じられている. 第13図と污れた 面と清浄な面についての結果を比較して示す。またこの 実験が方法によつてイオン衝撃をした金属表面は，フラ ッシュした面と全く同様に吸着ガスのない清浄面である ことも証明され，イオン衝撃がこの目的にも使われるよ らになつた。

\section{(5)超高真空における冷電子放射 とイオン放射}

タングステン線を曲率半径 $1000 \AA$ 程度以下に細く尖 らして $10^{7} \mathrm{~V} / \mathrm{cm}$ 程度の強電界を加えると冷䉓子放射が 扣こり,これを螢光膜にうけると尖耑の拡大像が兄ら れ, これを field emission microscope 之呼ぶ. 現象と しては以前から知られ, その倍率が 107 亿達するので 特殊の顕微鏡として結晶学, 吸着などに利用されてき た. 尖端の 1 個の単結晶の結晶面は仕事函数がちがうの で像の明暗となつてあらわれる。しかしこの顕微鏡内部 伐留ガスがあるとガス吸着のため清浄な表面像がえら れずまたイオンが逆に尖端に衝突して尖端の寿命を短 くするが，超高真空にすれば安定な顕徽鏡が容易に得ら れる.ことに極低温の利用によつて金属表面における吸

(26) H.D.Hagstrum: Phys. Rev., 104 (1956),317,672, 1516; J.Appl.Phys., 31 (1960), ,715.
着原子の易動度や，吸着熱などについて多くの研究がな された(27)、たと究ば、タングステン上の単原子酸素吸着

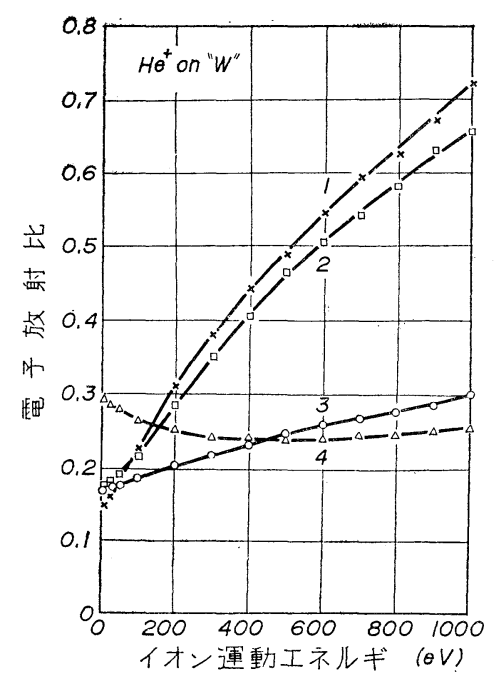

(a)

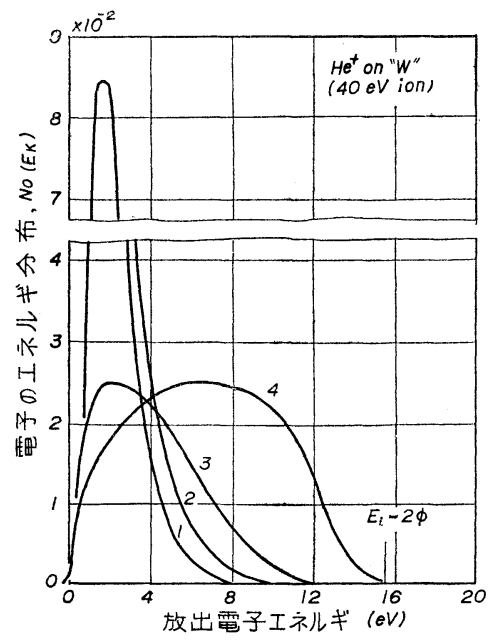

(b)
第 13 図電子放射比亡放出電子のエネ ルギ分布， 1: 污れた面， 4 : 清浄な面 (Hagstrum) 層は $400^{\circ} \mathrm{K} て ゙$ 活性化 $\simeq$ 采 ルギ $30 \mathrm{kcal} /$ mole t存子 て動きはじめ るが，多量に 吸着した部分 は活性化土ネ ルギが小さく $40^{\circ} \mathrm{K}$ でも移 動をすること がわからた。 他の系につい てもいろいる な研究がなさ れている。

通常の真空 管㓌極の代り にこの冷電子 放射を利用す ることは当然 考えられると ころである が, 放射電流 を增すために は高電压また は極く細い尖 端が必要で, これはイオン 衝撃による寿 命低下をもた らすため笑現 は不可能であ つた。しかし 最近になつて超高真空技術を利用することによりイオン 衝撃を減少させることがでさて実用領域(28)にはいつて きたすすなわち入念なガス出しと, ヘリウムの内部拡散 を防止する器壁材料との組み合せによつて, 充分の長時 間封じ切つた真空管の内部の圧力を超高真空に保つこと ができた. 10-6 ̊ 程度の曲率半径をもつタングステン 尖端を陰極とし，放射電流密度 $107 \mathrm{~A} / \mathrm{cm}^{2}$ で寿命は1000

(27) R.Gomer: Adv.in Catalysis, 7(1955) ,93; R. Wortman, R.Gomer and R.Lundy : J.Chem. Phys., 26(1957),1147 その他

(28) W.P.Dyke: I.R.E.MIL-4 (1960), 38 . 
時間以上 10,000 時間程度のものが試作されている。針 を並べて立てることによつて全電流は 0.1A 程度末で, 電压は1ないし $10 \mathrm{kV} て ゙$ 動作する。この真空管は陰橔 加熱電力が不要なため熱的設䚵が容易で小型化でき, か つ起動の特くれがない。この性筫は最近のモレクトロニ クス飞必要な部品の極小化化適当して和り, 別の報告で は配線用基板に埋达九だ状態で組み上げていくこともで き, 1011 個の真空管赏 1 インチ立方化収容す多可能性も 古るという。この場合電子走向時間は 10-13 秒程度なの でスイッチ要素としてみても, スイッチ時間が短く, $1 \mathrm{~mW}$ の入力学総計で矫秒 $1015 \mathrm{bits}$ の動作をさせられる という.

またマイクロ波真空管化も応用されて扮り，少くとも 10,000 MC までは電子放射の括くれのないことが実験的 汇確かめられた。冷電子放射は電界飞非常㳊感で, 電 界制御が有效なため空洞共振器の高周波電界でも直接電 子放射を制御できる。秃をFemitronと名付ける。こ れはとの特性上增川器や周波数增倍器として效率がよ い。もつとも有效な用途㥒間X線管の電子源である

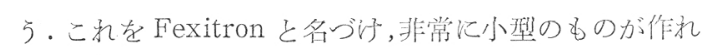
るため人体内部などX線撮影の新しい分野が開ける。瞬 間電力は $0.2 \mu \mathrm{sec} て ゙ 300 \mathrm{MW}$ のものが作られている.

上記の強電界飞上る電子頙微鏡と同じ構造で, イオン

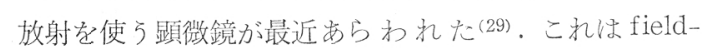
ion microscopeで, 超高真空保つた容器飞微量の一 リウムを導入すると, タングステン尖端の強い電界でイ オン化され，逆の印加電圧化よつてスクリーンに加速投 影されるオ法で, イオンは電子上りも垻量が大きいため 波動光学的な分解能が木貿的にすぐれており, さらに液 体へリウムで泠却寸ること注つて $1 \AA$ 程度の分解能が

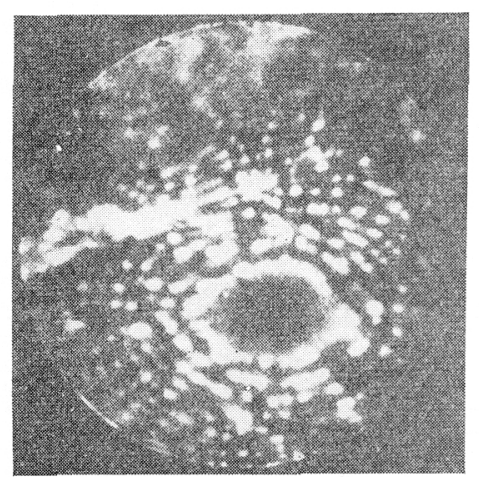

第 14 図 タングステン (011) 面付 近に者る転位の像 (Mü1ler)
すでに実駱的 飞得られてい る.この顕微 鏡が间能にな つたの涩, 極 低温化よつて 分解能が问上 寸名添か飞人 リウム以外の ガス分压が寒 になるため， 妨害のまつた くない清浄な

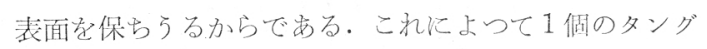
ステン原子の举動, 表面化存在す名 1 倜の転位や原子空

(29) E.W.Müller: J.Appl.Phys.,26(1957), 1.
孔などを直接観察でさるようになつた。これは現在もつ とも高い分解能をもつ顕微鏡で方る。第14図にタング ステン表面の 1 個の転位、を示与。

\section{(6)金属の接触抵抗と超高真空(30)}

金属接点の示可接触抵抗は表面酸化物または吸着ガス によつては性質が左右され，これが䒠用的に重大な意味

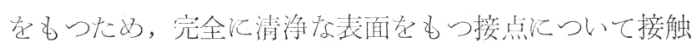
抵抗の研究が超高真些中で行なわれた。

タングステン線またはモりブデン線を 10-10 mmHg 中 でフラッシュして, これ老任意の荷重のもとで接触させ

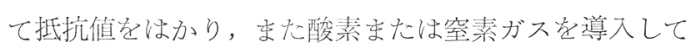
その初期吸着層の影響を調べた。フラッシュ温度ととの 後の接触抵抗の関係からタングステン，モリブデンとも に約 $1700^{\circ} \mathrm{K}$ のフラシュで完全に清浔になることがわ かりこのことから吸着熱は $100 \mathrm{kcal}$ 程度であること 汭り吸着实験の絬果と一致する。この関係を第 15 図

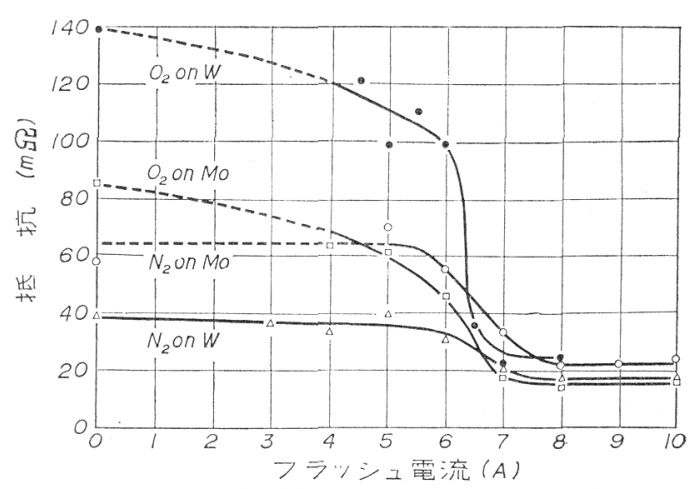

籍 15 㘠接触抵抗とフラッシュ温度の関係, 荷重 $1 \mathrm{~g}$ (Kisliuk)

飞示す。このときの接触抵抗はspreading resistanceの

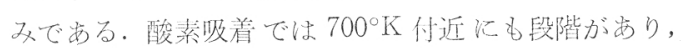
これ深分子吸着と想定世られた。酸素, 窒素とも飞初期 飞は早い吸着があり。これは10-10 $\Omega-\mathrm{cm}^{2}$ の接触比抵抗

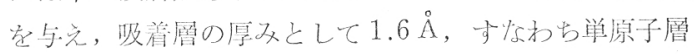
程度に相当することもわからた。 $100^{\circ} \mathrm{K}$ の低温で财着し た物理吸着層は排気しただけでは全部はとれないこと， またガス吸着層は接点間隙を山入することは㗭いことな ぞが確認され，従来の説が訂正された。特そい吸着部分 は窒素では少いが, 酸素では際限なく続き酸化汭な ることもわからた。

\section{(7) 金属薄膜の構造}

超高真空中で蒸着して作る金属はガスの吸着ないし含 有がないため, その意味に扔ける不純物を含さことがな い. 磁性または超伝導現象の上万な物理現象はごく促か の不純物でもいらじるしくその㤸性を变えることが知ら

(30) P.Kisliuk: BSTJ, $37(1958), 925$. 
れて括り, 事実超高真空中で作つた薄膜と通常の高真空 中で作つたものとを比較すると両者の特性がいちじるし く異なる場合がある．以下にその例をのべる．

強磁性薄膜は電子工学で最近注目されているものであ り, この飽和磁化は Klein-Smith の理論とよるとBloch のスピン波を適当な条件で積分することによつて得られ

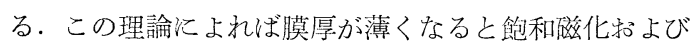
Curie 点が低下寸る.ニッケルでは約 $1000 \AA$ 程度からバ ルクの值より低くなりはじめ, ついに室温では $20 \AA ̊ 丿$ 厚さで磁化が消失するはづである。この理論はその後多 くの実験的支持を得て薄膜特有な磁気的性質とみなされ ていた．ところが Neugebauer(31) は 10-9 mmHg の超高 真空中でニッケルを蒸着してそのままで外に出すことな しにトルクメータで飽和磁化を测定できる装置を作つ た.これによると意外にも薄膜の飽和磁化はバルクと変 らなかつた、 $15 \AA$ 程度以下の厚みでやや減少をはじめ るが，これは超パラ磁性によるものである。そこで從来 の真空装置で作つた薄膜てついて得られた絬果は再検討 せねね゙ならなくなつた・膜が薄いと酸化の影響をうけや すいため飽和磁化は低く出やすい，従つてこの現象は微 量の酸化物によるものと考光られるがまだ決定的ではな い.しかし 10-4\%の微量酸素が磁気特性を決定すると いう研究もある. 超伝導薄膜も電子工学で活発にとりあ げられているが，錫の薄膜を通常の真空中で蒸着すると その臨界温度がバルクの值と一致せず, 超伝導になりに くいことがある.この原因としては蒸着膜内部の格子欠 陥(これは温度条件できまる)のほかに, 蒸着中の不純物 の影響が問題になる場合がある.タンタルを蒸着すとき, 通常の真空の下ではよい特性が得られないが，10-11 $\mathrm{mmHg}$ の超高真空中で充分注意してガス出しした石英 板上に蒸着するとバルクと同じ特性をもつことがふかか た (32). 化学的に活性な金属はゲッタ作用があるから, 真 空に注意しなければならない，窒素中でタンタル線を加 熱する方法で窒素含有量を变えて臨界磁界を調べてみる と 10-4 ないし 10-3 原子\%程度の含有量がすで影響を 示したのである.

電子顕微鏡による観察のためのレプリカについては超 高真空中で作られた試料表面上の蒸着膜の生成状態は従 来のものとかなり異なることがあきらかになつた(33).

雲母の上に白金を超高真空中で蒸着したものは単位微結 晶が大きく揃つて抢り,(これは表面の污れが少いときは

(31) C.A.Nengebauer: Phys. Rev., 116 (1959) ,1441; J.App1.Phys., 31 (1960), 152-S.

(32) J.F.Marchand and A.Venema: Philips Res. Rept., $14(1959), 427$.

(33) L.Bachmann, W.H.Orr, T.N.Rhodin, and B. M.Siegel : J.App1.Phys.,31 (1960), 1458.
到着原子の表面移動が大きいためであるが）この膜をシ +ドゥの目的に使うときには, 陰影が普通の場合よりも はつきりすることがわかつた。また蒸着マグネシウム膜 の表面レプリカをとる目的でその上に白金を被覆するさ い, マグネシウム面か酸化しているときと超高真空のま まで保持されたときとは結果炕きな羙が認められた。 酸化表面上につ外た白金は下地汇影響された不均一な成 長を示すが，清浄なマグネシウム面上では両者の合金化 が执こつてしまう。これは清浄表面の特質であるが, こ れを防ぎたい時には両者の中間汇超高真空のままで蒸着 カーボン膜を挾めばよい。

\section{4. 超高真空と半導体}

\section{（1）清 浄表面と表面準位}

よく知られているように, 半導体の電気的性質は禁止 帯に位する不純物準位に支配されている上らに，これと よく似た性質の準位が表面にも存在し, 表面の性質を決 めていることが各種の実験を通して明らかとなつてい る. その発生の原因は 2 通り考光られていて, その一つ は表面は相の境界面であるため, 結晶内の周期的ポテン シャルがそこで崩れ，必然的に表面特有の準位が発生す るという考方方で, すでに 20 年以上も前にTammや Shockley が理諭的にその可能性を指摘している. この 考え方にしたがえば，Ge や Si などの共有結合結晶で は，表面原子は外に向いた結合手が余つている (dang1ing bond と呼ぶ)ので電子を捕えることが出来る.それ ゆ兄表面準位の状態密度は原子の表面密度と同じはづで 約 1015 states $/ \mathrm{cm}^{2}$ となる。ところが実際の $\mathrm{Ge}$ 表面に招 ける実測値はこれょり少く，1010〜1013 states $/ \mathrm{cm}^{2} て ゙$ あ つた。この理由は表面はすで酸化しているので, 酸素 原子が dangling bond と結合して準位を埋めてしまう ためと考光る。表面準位のもら一つの発生機構は,酸素, 水蒸気などのガスが内部から電子または正孔をとつて表 面に化学吸着する時, 電子や正孔の入る準位が表面準位 となるといら考方方である。 そこでこれらの酸化物やガ ス吸着層を取除いてやれば半導体固有の表面準位が検出 できるだろうとの予想の下に, 清浄表面の研究が始めら れた。

金属の清浄表面の実験では通常異種原子を単分子層の 数パーセント以下に減らした表面を报うことが多い。こ れは熱電子放射やガス吸着の立場から見た場合, この程 度の污れは金属では殆んど測定にかからないからであ る.ところが半導体表面では，たと光単分子層の $1 \%$ の 污れが表面に存在しても, これが表面でイオン化する と, この電場を遮蔽するため $10^{-4} \mathrm{~cm}$ 位の深さまで空間 電荷層が形成されてキャリャーの分布を変え，極端な場 
合には表面で縮退してしまう。それゆえ半導体では外部 表面上の不純物の 2 次元的濃度を $1 / 100$ 単分子層以下に 減らすと同時に，表面から垂直方向の結晶内部の不純物 濃度をも制御する必要がある. Brattainによれば半導体 の clean surface と情面第二層以下結晶内部に到る屯 で,化学組成が一様で, 同侍に表面第一層の上には異種原 子が単分子層の百分の一以上存在しない表面のことであ る.このよ5な半導体表面と金属表面との差異はいらま でもなくキャリャー濃度の格段の差に基因するもので， この点を念頭に扔いて以下半導体清浄表面の研究動向を 紹介する.

\section{(2) 清浄表面(34) の作り方と試験法}

いままでに $\mathrm{Ge}, \mathrm{Si}$ のエッチ面から 10〜 $50 \AA$ 程度の表 面酸化層を取去つて清浄化するには，次の(i)〜 (iii) の 方法が試みられた.

（i）超高真空中で結晶を融点近くまで電流加熱して表 面の酸化物を蒸発させる。これは高融点金属の場合の flash-filament 法に相当する。例えば Geでは $1 / 2 \mathrm{Ge}$ (s) $+1 / 2 \mathrm{GeO}_{2}(\mathrm{~s})=\mathrm{GeO}(\mathrm{g})$ なる反応で生成する低 級酸 化物 $\mathrm{GeO}(\mathrm{g})$ の蒸気圧は $1000^{\circ} \mathrm{K}$ で $9.3 \times 10^{-1} \mathrm{mmHg}$, $\mathrm{Si}$ では同様の反応で出来る $\mathrm{SiO}$ 蒸気圧は $1200^{\circ} \mathrm{K} て ゙$ $10^{-1} \mathrm{mmHg}$ 位である。

(ii) 水素や一酸化炭菜で酸化物を睘元し, そのあと加 熱ガス出しする.

(iii)予め $600^{\circ} \mathrm{C}$ 以上に加熱ガス出しを行なつてから $500 \mathrm{eV}$ 程度の稀ガスイオン（主としてアルゴンを使う） で表面を衝撃して酸化物や下地の一部をスパッターし,

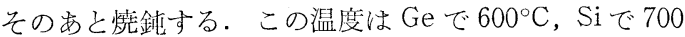
${ }^{\circ} \mathrm{C}$ 以上が適当とされている。また全く新しい表面を作 るには

(iv) 超高真空中で結晶を粉研，ぬたは䢃開する。

（v）蒸着膜を作る(ただし多結晶).

このよ5にして得た表面の清浄さは，金属で見出され た表面钽感性，すなわち低速電子回折，イオンの衝突に よる電子の Auger ejection, 光電子放射, ガス吸着速度 などにより調べられた. Farnsworthら(35)によれば, (iii)のイオン衝撃は表面の原子配列を乱すため, 明瞭な 回折像が観測されないが，そのあと $600^{\circ} \mathrm{C} て ゙$ 燒鈍すると 再現性のある半整数次の回折線が，整数次回折線に混じ つて現われ，酸素を導入すると前者は消える。この結果 から彼らはGeについて表面原子の配列に超格子構造を 推定した。 また Hagstrum は(26)(36) 3 章でも触れたよう

(34)ここでは “cleaned” surface を指し，必ずしも “ideal” surface ではない. ideal surfaceを作る ベく処理した表面のことである.

(35) R.E.Schlier and H.E.Farnsworth: Semiconductor Surface Physics, (1956) ,3.
に Auger ejection をGe, Si 結晶について測り，金属の 場合と同様表面の污れが 2 次電子放射比に影響するこ と，原子配列の乱れはきかないことを見出した。これら の穾験結果は (i) の真空加熱法では最後の単分子酸化層 が取去れない。(iii)の才法により，はじめて再現性のめ る清浄表面が作られることを示している。

一方酸素吸着速度は粉体にも適用出来る清浄さの測定 基準である。よくガス出しした Ge 薄片を超高真空中で マグネチックハンマーで破砕して得た $\mathrm{Ge}$ 新鮮面の酸素 吸着速度を(ii)，(iii)，(v)の方法で得た表面のそれとを 比べると, 初期吸着量 (ほ㳯箪分子層) と, その後の吸着 速度 (Elovichの式) は極めてよく一致する(37)。また Si では吸着速度以外に外部光電効果, 冷電子放射顕微鏡に よる観測から，エッチ面を $1550^{\circ} \mathrm{K}$ で数分間フラッシュ すれば酸化層はすべて取去られて，2次元的には清浄表 面が生成することが確められている(38).

Ge,Si の絬晶は(111) 面, InSb は (110) 面が䢃開面と なる. 試料に切込久を入れ，この中に楔を打込むとか (39)，結晶薄片の一端を固定し，他端に曲げ応力を加えて 折る方法が知られている(40). 割つた後の断面を観察す ると, 引張り応力のかかつた上半分は平滑で, 圧縮応力 のかかる下半分は粗面となる．前者を電子顕微鏡で観察 すると，50〜 500Å の cleavage step が数千 凤 の間隔で 並び, step間は完全に平らである.この方法で機械的歪 が表面層に残るか否かは未だ判つていない。

\section{(3) 表面伝導と不純物の効果}

(i), (ii), (iii)の表面処理で得られる清浄表面は, 結晶 の伝導型に無関係に強い $\mathrm{p}$ 型伝導を示すとい5点につい てはすべての実験結果は一致している，Handler(41)によ れば n 型 Ge に (3) の表面処理を施すと, 表面伝導は增 しホール係数は減る. 前者はキャリャーの增加を意味 し，それにも拘らずホール係数が下ることはn 型伝導に 正孔伝導が加わつたことを示す.酸素を $10^{-5} \mathrm{mmHg}$ 以 上入れるとこの正孔伝導は消える。また縦電場効果 (半 導体板と金属板を組合わせてコンデンサを作り，電圧を 印加すると, 誘導電荷量に応じて半導体内部の自由キャ リ + 数が增減し, 電気伝導度が変る現象）の測定から

(36) H.D.Hagstrum : Phys.Rev.,119(1960),940; J Phys.Chem. Solids, $14(1960), 33$

(37) 例党ば A.J. Rosenberg, P.H. Robinson and H. C.Gatos: J.Appl. Phys., $29(1958), 771$; S.P. Wolsky: Phys.Rev., 108(1957),1131.

(38) F.G.Allen, J.Eisinger: H.D.Hagstrum and J. T.Law: J.App1.Phys., $30(1959), 1563$.

(39) D.R.Palmer et al: J.Phys. Chem. Solids, 14 (1960) ,27 ; Phys.Rev.Letters, 6 (1961) ,170.

(40) G.W.Gobeli and F.G.Allen: ibid,23.

(41) P.Handler: Semiconductor Surface Physics, (1956) ,23 ; R.Missman and P.Handler : J. Phys.Chem.Solids, 8(1959), 109. 
も, Ge 清浄表面に $10^{13} \mathrm{~cm}^{-2}$ 以上の表面準位が存在し, 縮退した $\mathrm{p}$ 型伝導層が形成されていることが判つた. こ の結果より彼はTamm-Shockley 型表面準位の実在を 主張した. Dillon と Farnsworth(42)によれば,(iii)の処 理面の仕事函数 $\left(\varphi_{c} \doteqdot 4.73 \mathrm{eV}\right)$ は光電子のthreshold $\left(\varphi_{p h}\right.$ $\doteqdot 4.6 \mathrm{eV})$ より大きいことから, 丧面ポテンシャルは第 16 図で表わされ，Handler の主張を支持している.

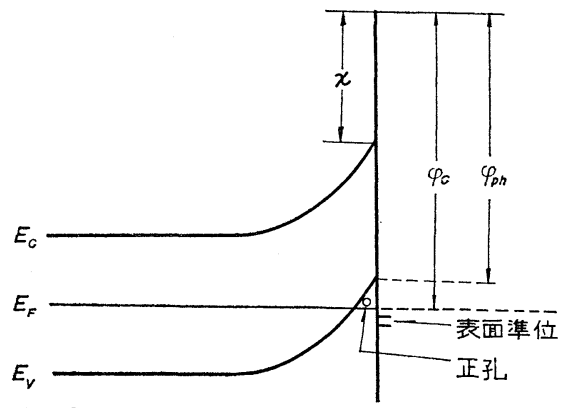

第 16 図 縮退した表面 $\mathrm{p}$ 型伝導層のエネ ルギ準位図

小林ら (43) は(i) の処理を行なつた Ge 表面に打いて, $10^{\circ} \mathrm{K}$ 以下で異常 $\mathrm{p}$ 型伝導が起り, これは空気に触れる と消隇することを見出した. 酸化される表面層の厚さは $100 \AA$ 以下であるから, この異常 $\mathrm{p}$ 型伝導はこの層内で 起ると考えられる. またイオン衝撃だけを行なつた面で は表面(44) はむしろ $\mathrm{n}$ 型で, 低温異常伝導は起らないが, そのあと熱処理をすれば表面はより $\mathrm{p}$ 型となり，低温で 僅か伝導性を増す。このことから低温異常伝導の原因は つぎに述べる経路を経て侵入した矹素の不純物伝導と見 なしている。

Bell 研究所では数年前から真空中で加熱処理した Si 面には常に $10^{4} \mu \Omega / \square$ に達与る強い $\mathrm{p}$ 型伝導層が出来る ことに気づいていたが，原因は判明しなかつた．Law (45) はこの原因を探究した結果, ベークアウト中ガラス 容器の壁面の硼素と残留水蒸気とが度応して $\mathrm{H}_{3} \mathrm{BO}_{3}$ 李 たは $\mathrm{HBO}_{2}$ 蒸気となり, 結晶表面を污す。高温加熱中に Siで還元されて硼素となり, 数 $\mu$ の深さまで払散して $\mathrm{p}$ 型不純物層が出来ることを指摘した。一旦加熱してこ の $\mathrm{p}$ 層が出来ると, これを取除くためには $1 \mathrm{coul} / \mathrm{cm}^{2}$ 以上のイオン衝撃を必要とする.この結果を考慮すると (i),(ii)の処理法は勿論 (3)の処理法で作つた清浄表面の データも再検討して見る必要があろう．何故なら (iii)の

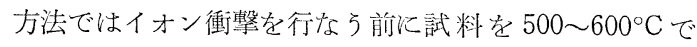

(42) J.A.Dillon, Jr and H.E.Farnsworth: J.App1. Phys., 28(1957) ,174; 29(1958), 1195.

(43) A.Kobayashi, Z.Oda, S.Kawaji, H.Arata, K. Sugiyama: J.Phys.Chem. Solids, $14(1960), 37$.

(44) A. Kobayashi, et al : J. Phys. Soc. Japan, 16 (1961) ,2481.
長特間ガス出しを行なうので，その間にかなり厚い $\mathrm{p}$ 層 が出来ている可能性が濃い。しかもその後の衝撃イオン 数はこのp層をスパッタしてしまうには不充分と思われ るからである。しかし前以て加熱しない時は $500 \mathrm{~V}, 100$ $\mu \mathrm{A} \cdot \mathrm{cm}^{-2}$ のイオン衝撃を 10 分間行なえばこの種の污 れは完全に除去できる。事実 Ge 圶加熱しないでイオン 衝撃を行ない(44), むるいは一度出来た $\mathrm{p}$ 層を大量のイオ ン衝撃で完全に取去つた Si 表面は(45) n 型になり, 加熱 すると $\mathrm{p}$ 型に転換するが，この時の表面エネルギ帯の吊 り上りは Handler やDillon ら程大きくなく，表面準位 密度も $10^{12} \mathrm{~cm}^{-2}$ と 1 桁低く幦開面のデータに一致する.

このように表面の清浄処理には不純物の侵入というや つかいな問題が伴い，さらにイオン衝撃は表面層の結晶 格子を乱すので, 話はますます複雑になる。これに比べ ると䢃開面の力が現状では信頼性のあるデータが得られ るものと思われる，例えば $\mathrm{p}-\mathrm{n}$ 接合を含んだ Si 試片を 折曲げて割つた (111) 断面で仕事囦数と外部光電効果を 測定し，第 17 図のごとき結果が得られている(40). 試料

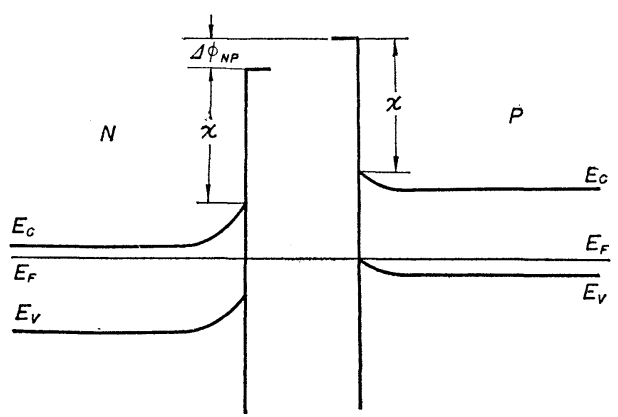

第 17 図 p-n 接合の両側表面のエネルギ淮 位図 (Gobeli), 接合の両側で $\left(\mathrm{E}_{\mathrm{F}^{-}}\right.$ $\left.\mathrm{E}_{\mathrm{V}}\right)$ の差が $1.0 \mathrm{eV}$ あつても䢃開面で は $\Delta \phi_{\mathrm{NP}}=\varphi_{\mathrm{N}}-\varphi_{\mathrm{P}}=0.15 \mathrm{eV}$ で, $\mathrm{n}$ 型の表面が袁面準位のため吊り上げ ら机ることを示す

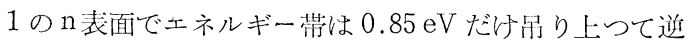
転層となるが，これは表面準位が Fermi 準位の下に約 $2 \times 10^{12} \mathrm{~cm}^{-2}$ の密度で存在することに対応する.また， 䢃開面で縦電場効果と表面伝導が測定されている(39). 同じ人が GeとSiを測つたにもかかわらず前者は $\mathrm{p}$ 型, 後者は $\mathrm{n}$ 型表面伝導といら結果になる有様で，いまの之 ころ Tamm-Shockley 型の表面準位の決定的な証明 は 得られていないと考えられる.

\section{5.むす び}

Alpert の研究以後 10 年足らずの中に, 超高真管技術 は飛躍的な発展を遂げ, 小型实験室装置では 10-11

(45) J.T.Law: J.Phys. Chem. Solids, 14(1960),9. 
$\mathrm{mmHg}$ までの真空は容易に得られ，かつ測れるように なつた. 現在確実に測られた最高の真空は 10-14 $\mathrm{mmHg}$ である. 大型化に関しては各種金属部品やポンプの検討 が行なわれて $10^{-10} \mathrm{mmHg}$ まで到達可能となつている. この技術により，金属や半導体で清浄な表面が作られ，
従来の真空技術では得られなかつた新しい知見がつぎつ ぎに生れつつある。また装置の大型化によりさらに新し い応用面が開拓されてくることが期待される。

終りに原稿を通読し批判していただいた小林秋男室長 に感謝します。(了)

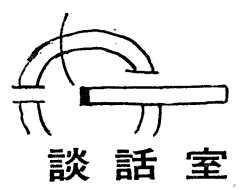

\section{卵は何時でも立つ}

会報創刊号が会員の手に渡つた。まず明かるい斬新 な表紙が目にうつる。多くの犠牲をはらつて産みださ れた会報は，会員に訴えるものもまた多いことである 5.ようやく 1 月号が発刊されると, 編集部はさらに 2 月, 3 月と各号のよりよさ発展を期して活動をつづ けている状態である。

2月ともなれぼ心なしか陽あしの長さが感じられ る. 退汀時の 5 時になつても外は幾分の明るさを残 し，帰宅もつい遅れがちとなる。この立春の頃ともな れば私はよく“立春の卵”を思い出す。それは太陽の 視黄径が $315^{\circ}$ になっ時だといら説明よりもさきに 私の頭にうかんで来ることである。

1947 年, 戦後の暗い空気の中で, 立春に卵が立つた といら写真入りのニュースはひぞく私の関心をとらえ た、黑いピアノの上に数個の卵が並んでいた。それは いまでも私の眼底に焼きついている，立春には卵が立 つということは，支那の “秘密の万華鏡”という古書 から発見されたそうだ。昔から“コロンブスの卵”と いわれたように，長い間世界中で卵は立たないものと 思われていたから，この事穾に対し多くの学者の関心 が集つたのも当然である。なかでも北大中谷教授の報 告はその最も科学的なものといえよう。教授は卵を顕 微鏡で調べて，卵の表面の凹凸は波形をなし，その波 長は約 $0.8 \mathrm{~mm}$ であることを発見し “五德の脚説”で 見事に解答を与えたのである。

そこで私は早速卵を持ち出して試みると，なんとみ ごとに卵は机の上に立派に立つたのである，家族も各 自卵を立てることに成功した。その頃私の研究室を訪 れた人々は，みな卵を持ち出されて思いが汁ない経験 をされたものだつた。この頃でもこれを利用して物体 の安定の講義になると, 壇上で机の上に卵を立ててみ る。また，すき焼のときなど，興がわけば卵を割る前 に漆塗りの盆の上に立ててみる。こんなとき三昧境に 入ると卵があたか子底に鉛が裏付けされているかのよ らにヒョイと起き上つてくるのを感ずる，その妙味は
忘れがたいものがある。

さて中谷教授の卵の報告は“これは人類の盲点の存 在を示す好個の一例である”といら言葉で結ばれてい る、われわれの学術研究のなかにもとらした言点があ るのではなかららか，後からみれば実に当然過ぎるこ とであつても，それを何故か実験し得なかつたという 経験をもつことがしばしばあるのではなかららか，発 明発見などのなかには，この盲点に光をあてた結果に よるものが相当あるのではないかと思われる。

日刊工業新聞社では 1961 年の十大新製品を選定し 表彰を行なつている，各社の新製品を産又出すまでの 苦心談が揭載されていたが，TK-8磁不の発明者の言 葉の中に“普通にやつてみたが駄目なので反対にやつ てみた”というのがあつた。これは恐らく常識的には 不可能と思われていたところが盲点であつて，これを 究明することによつて成功したものだと考えられるの である。立春の卵で暗示されるように多くの盇点が存 在していることを考虑に入れて研究を進めてみたいと 思5.

い屯試みに磁石の例をとつたついでに，私事で恐縮 ではあるが，析出磁不の低温処理の場合はどうであつ たかふりかえつてみよう。析出磁石の特性を最高にす る熱処理としては，まず溶体化の高温度Ts，たとえぼ $1300^{\circ} \mathrm{C}$ に加熱し, つぎに最適析出温度 $T$ p, たとえば $600^{\circ} \mathrm{C}$ に加熱することになつている。 したがつてTp 以上に磁石を加熱することは磁性が劣化するので禁じ られていた。このへんが問題なのであつて, Tpより は高温であるがTS より遙か低温の $875^{\circ} \mathrm{C}$ に加熱す ると磁性は確かに劣化するが，これを再びTpで加熱 すると, 案に相違し特性は Ts 加熱の場合と同程度, またはそれを越すほどになつた。常識的には悪いと思 われる事柄については，一応その型をはずして見るこ とも考えれてよいのかも知れない。

さて会報の本号を見ていただこう．この原稿を書い ているいまはどんなものになるかは全然わからない が，ただ会員諸兄の会報とすることこそが，編集者一 同の願いであることはたしかである、編集者と読者と 立場が異なれば,われわれのこの仕事の盲点にも諸兄 から十分に光をあてて頂けることと思う。隔意なき御 意見を披歴され，指導されんことを願つて擱筆する。

(白川 勇記) 